\title{
Dynamic aspects of ammonia and urea metabolism in sheep
}

\author{
By J. V. NOLAN and R. A. LENG \\ Department of Biochemistry and Nutrition, The University of New England, \\ Armidale, NSW, 235I, Australia \\ (Received 27 April I97I - Accepted 4 May 1971)
}

I. To obtain a quantitative model for nitrogen pathways in sheep, a study of ammonia and urea metabolism was made by using isotope dilution techniques with [ $\left.{ }^{15} \mathrm{~N}\right]$ ammonium sulphate and $\left[{ }^{15} \mathrm{~N}\right]$ urea and $\left[{ }^{14} \mathrm{C}\right]$ urea.

2. Single injection and continuous infusion techniques of isotope dilution were used for measuring ammonia and urea entry rates.

3. Sheep were given $33 \mathrm{~g}$ of chaffed lucerne hay every hour; the mean dietary $\mathrm{N}$ intake was $23^{\circ} 4 \mathrm{~g} / \mathrm{d}$.

4. It was estimated that $59 \%$ of the dietary $\mathrm{N}$ was digested in the reticulo-rumen; $29 \%$ of the digested $\mathrm{N}$ was utilized as amino acids by the micro-organisms, and $71 \%$ was degraded to ammonia.

5. Of the $14.2 \mathrm{~g} \mathrm{~N} / \mathrm{d}$ entering the ruminal ammonia pool, $9.9 \mathrm{~g} \mathrm{~N} / \mathrm{d}$ left and did not return to the pool, the difference of $4.3 \mathrm{~g} \mathrm{~N} / \mathrm{d}$ represented recycling, largely within the rumen itself (through the pathways: ruminal ammonia $\rightarrow$ microbial protein $\rightarrow$ amino acids $\rightarrow$ ammonia).

6. Urea was synthesized in the body at a rate of $18.4 \mathrm{~g} \mathrm{~N} / \mathrm{d}$ from $2.0 \mathrm{~g} \mathrm{~N} / \mathrm{d}$ of ammonia absorbed through the rumen wall and $16.4 \mathrm{~g} \mathrm{~N} / \mathrm{d}$ apparently arising from deamination of amino acids and ammonia absorbed from the lower digestive tract.

7. In the $24 \mathrm{~h}$ after intraruminal injection of $\left[{ }^{15} \mathrm{~N}\right]$ ammonium salt, $40-50 \%$ of the $\mathrm{N}$ entering the plasma urea pool arose from ruminal ammonia; $26 \%$ of the ${ }^{15} \mathrm{~N}$ injected was excreted in urinary $\mathrm{N}$.

8. Although $5^{\circ} \mathrm{I} \mathrm{g} \mathrm{N} / \mathrm{d}$ as urea was degraded apparently in the digestive tract, only $\mathrm{I} \cdot 2 \mathrm{~g} \mathrm{~N} / \mathrm{d}$ appeared in ruminal ammonia; it is suggested that the remainder may have been degraded in the lower digestive tract.

9. A large proportion of the urea $N$ entering the digestive tract is apparently degraded and absorbed and the ammonia incorporated in the pools of nitrogenous compounds that turn over only slowly. This may be a mechanism for the continuous supply to the liver of ammonia for these syntheses.

I0. There was incorporation of ${ }^{16} \mathrm{~N}$ into bacterial fractions isolated from rumen contents after intraruminal and intravenous administration of $\left[{ }^{15} \mathrm{~N}\right]$ ammonium salts and [15 $\left.\mathrm{N}\right] \mathrm{urea}$ respectively.

II. A model for $\mathrm{N}$ pathways in sheep is proposed and, for this diet, many of the pool sizes and turn-over rates have been either deduced or estimated directly.

The feeding of non-protein nitrogen supplements to ruminants is based on the knowledge that ammonia is the major end-product of the degradation of proteins in the rumen (McDonald, 1962), and on the belief, which appears to have been generally accepted, that most of the $\mathrm{N}$ utilized by micro-organisms comes from the ammonia pool in the rumen. Ruminants have been maintained on diets in which the only source of $\mathrm{N}$ was either ammonium salts or urea (Loosli, Williams, Thomas, Ferris \& Maynard, I949; Virtanen, I966), indicating that all the essential amino acids for nonruminants can be synthesized from ammonia by the ruminal micro-organisms. It has been considered that the low concentrations of amino acids occurring in ruminal fluid result from rapid deamination of the free amino acids to keto acids and ammonia (elShazly, 1952; Lewis, 1955; Warner, 1956) rather than from rapid uptake of amino 
acids by micro-organisms even though some micro-organisms are known to have an obligatory requirement for peptides or amino acids per se (Hungate, I966). Perhaps because of the technical difficulties associated with measuring the rates of uptake of amino acids by micro-organisms (Portugal, 1963), the possibility that appreciable quantities of amino acids are utilized by the organisms in the rumen has not been studied more extensively in vivo. These difficulties have also made estimates of the rates of production of amino acids in the rumen difficult to obtain (Portugal $\&$ Sutherland, 1966 ).

Indications of the rates of ammonia production in the rumen have been obtained from in vitro estimates (Bloomfield, I961; Phillipson, Dobson, Blackburn \& Brown, 1962) or from the concentration of ammonia in ruminal fluid (Hogan, I 964). However, concentrations of substrate in ruminal fluid or blood are difficult to interpret in quantitative terms without measurements of rates of synthesis. Direct estimates of the rate of production of ammonia in the rumen of sheep were reported recently by Pilgrim, Gray \& Belling (1969), and by assuming a value for the rate of recycling of endogenous urea to the rumen, they were able to propose a quantitative model for $\mathrm{N}$ metabolism in the rumen. There has been considerable qualitative evidence for the utilization of endogenous urea in the rumen (see Smith, 1969), but no direct estimates of the quantitative transfers of urea $\mathrm{N}$ from blood into the upper and lower digestive tract of feeding sheep have been reported.

In the studies now reported $\left[{ }^{15} \mathrm{~N}\right]$ ammonia and $\left[{ }^{15} \mathrm{~N}\right]$ urea and $\left[{ }^{14} \mathrm{C}\right]$ urea have been used to examine rates of entry of ammonia into the ruminal ammonia pool, and urea into the body pool in sheep respectively. Estimates of the contribution of ruminal ammonia $\mathrm{N}$ to plasma urea, and the entry of urea $\mathrm{N}$ into the ammonia and microbial $\mathrm{N}$ pools in the rumen were obtained. Utilization of endogenous urea returned to the rumen by micro-organisms was also shown. Techniques used in the present studies enable many of the rates of transfer of $\mathrm{N}$ between the various pools of $\mathrm{N}$ in the rumen and in the body to be deduced or obtained directly such that a model of $\mathrm{N}$ metabolism in the whole animal may be quantitatively described.

\section{MATERIALS AND METHODS}

\section{Experimental animals}

Six adult Merino ewes (aged 2-3 years) each fitted with a rumen cannula were used in these studies. Sheep designated A, B, C, D were used in the first series of experiments, and $\mathrm{E}$ and $\mathrm{F}$ were used in the second series of experiments. The animals were housed singly in pens and given $800 \mathrm{~g}$ lucerne $(20-26 \%$ crude protein) daily for several months before the studies were commenced. Before each experiment the ewes were placed in metabolism cages in a room which was continuously illuminated. For the $5 \mathrm{~d}$ before injection of isotopes, the ewes were given a daily ration of $800 \mathrm{~g}$ lucerne chaff in equal portions at hourly intervals. 


\section{Experimental procedures}

Catheters were inserted into both jugular veins of each animal $12 \mathrm{~h}$ before each experiment, one to be used for isotope administration, and one for collecting blood samples. On the ist day $\left[{ }^{15} \mathrm{~N}\right] \mathrm{ammonium}$ chloride (into the rumen) and on the 2nd day $\left[{ }^{15} \mathrm{~N}\right]$ urea (into blood) were administered as single injections of isotope in the first series of experiments, and as continuous infusions of isotope in the second series of experiments.

In the first series of experiments two sheep (A, B) received an aqueous solution $(100 \mathrm{ml})$ of $\left[{ }^{15} \mathrm{~N}\right]$ ammonium chloride (approximately $260 \mathrm{mg}, 95 \%$ enriched with ${ }^{15} \mathrm{~N}$ ) and $\left.{ }^{51} \mathrm{Cr}\right] \mathrm{EDTA}$ ( $\mathrm{I} 6 \mu \mathrm{Ci}$ ) in $\mathrm{H}_{2} \mathrm{O}$ as a single injection into the rumen. This mixture was injected rapidly into the posterior part of the ventral sac of the rumen and mixing was aided for a short time after the injection by mechanical stirring. A single injection of $\left[{ }^{14} \mathrm{C}\right]$ urea $(50 \mu \mathrm{Ci} ; 50 \mathrm{mg})$ was made intravenously into these sheep on the same day. On the 2nd day, two other sheep (C,D) were subjected, as far as possible, to the same conditions as the sheep used on the Ist day, and were given a single injection of a mixture of $\left[{ }^{15} \mathrm{~N}\right]$ urea $\left(2 \mathrm{I} 7 \mathrm{mg}\right.$ of $97 \%$ enriched) and $\left[{ }^{14} \mathrm{C}\right]$ urea $(50 \mu \mathrm{Ci} ; 50 \mathrm{mg})$ intravenously. A single injection of $\left.{ }^{51} \mathrm{Cr}\right] \mathrm{EDTA}(\mathrm{I} 6 \mu \mathrm{Ci})$ was made intraruminally in these animals the following day.

In the second series of experiments, on the Ist day, one sheep (E) received a continuous infusion of $\left[{ }^{15} \mathrm{~N}\right] \mathrm{ammonium}$ sulphate $(0.58 \mathrm{ml} / \mathrm{min}$ of $0.19 \mathrm{mg} / \mathrm{ml}$ solution of $97 \%$ enriched ammonium sulphate) intraruminally and a continuous infusion of $\left[{ }^{14} \mathrm{C}\right]$ urea $(0.28 \mathrm{ml} / \mathrm{min} ; 0.3 \mu \mathrm{Ci} / \mathrm{ml})$ intravenously. The other sheep (F) received a mixture of $\left[{ }^{15} \mathrm{~N}\right]$ urea $\left(0.28 \mathrm{ml} / \mathrm{min}\right.$ of $0.2 \mathrm{mg} / \mathrm{ml}$ of $98 \%$ enriched urea) and $\left[{ }^{11} \mathrm{C}\right]$ urea $(0.28 \mathrm{ml} / \mathrm{min} ; 0.3 \mu \mathrm{Ci} / \mathrm{ml})$ intravenously. On the 2 nd day, a week later, sheep $\mathrm{E}$ received $\left[{ }^{15} \mathrm{~N}\right] \mathrm{ammonium}$ sulphate intraruminally.

\section{Sampling}

Samples of ruminal fluid were taken at intervals from the anterior ventral sac of the rumen. Each sample $(8 \mathrm{ml})$ was obtained, free of large particulate matter, by suction through a perforated plastic tube covered by fine nylon gauze and was transferred immediately to a centrifuge tube in ice.

Blood samples were placed in heparinized centrifuge tubes in ice, and centrifuged at $3000 \mathrm{~g}$ for to min. The plasma was stored at $-20^{\circ}$. Urine was collected by using bladder catheters inserted on the day of isotope administration, except during the ist day of the first series of experiments when urine was collected quantitatively from animals in a metabolism cage. Faeces were taken from the rectum and stored at $-20^{\circ}$.

\section{Separation of bacterial cells}

The samples of ruminal fluid were centrifuged at $16000 \mathrm{~g}$ for $15 \mathrm{~min}$ in a refrigerated centrifuge and the supernatant liquid was stored at $-20^{\circ}$. Bacterial samples were obtained by resuspending the remaining solid material in $10 \mathrm{ml}$ of saline containing a detergent (Brij-35 from Technicon, Sydney; $0.5 \mathrm{ml} / \mathrm{l}$ ) and centrifuging again. The supernatant liquid was discarded, and the layer of bacteria on the solid 
material was removed to another centrifuge tube by using a Pasteur pipette. The bacteria were resuspended in the detergent solution and again centrifuged. A bacterial sample was again taken from the bacteria layer remaining and this was subjected to Kjeldahl digestion. The bacterial sample obtained was examined microscopically and found to be free of plant material. The concentration of ammonia in the fluid containing the bacterial sample was less than $0.1 \%$ of that in the ruminal sample from which it was derived, so that enriched ammonia $\mathrm{N}$ would not have appreciably contaminated the $\mathrm{N}$ released from the bacterial sample during the Kjeldahl digestion.

\section{Laboratory procedures}

Ammonia $(0 \cdot 6-\mathrm{I} \mathrm{mg} N$ ) from ruminal fluid samples was collected into boric acid $(2 \%, \mathrm{w} / \mathrm{v})$ containing a mixed indicator (Bremner, 1965$)$ by steam distillation over $5 \mathrm{mg} \mathrm{MgO}$ (which previously had been heated for $3 \mathrm{~h}$ at $600^{\circ}$ to decompose any carbonate). This procedure was shown to release only ammonia from the ruminal fluid samples. After titration with $5 \mathrm{~mm}-\mathrm{H}_{2} \mathrm{SO}_{4}$ the boric acid-ammonia solution was acidified further with about $\mathrm{I} \mathrm{ml} 0.33 \mathrm{mM}_{-} \mathrm{H}_{2} \mathrm{SO}_{4}$ and evaporated to dryness at $100^{\circ}$, in small vials. These vials were later connected into the gas handling system of the mass spectrometer (Model MSro; GEC-AEI (Electronics) Ltd, Manchester, England). Ammonia derived from plasma urea was obtained as follows: the plasma samples $\left(5 \mathrm{ml}\right.$ ) were deproteinized with successive additions of $10 \mathrm{ml} \mathrm{H}_{2} \mathrm{O}, 5 \mathrm{ml} \mathrm{r} \% \%$ $(\mathrm{w} / \mathrm{v}) \mathrm{NaWO}_{4}$ and $5 \mathrm{ml} 0.33 \mathrm{M}^{-\mathrm{H}_{2}} \mathrm{SO}_{4}$. After centrifugation the filtrate was buffered to $\mathrm{pH} 6.5$ and then allowed to stand for several hours after addition of $5 \mathrm{mg}$ powdered urease from water-melon seed (British Drug Houses Ltd, England). This urease preparation contained no detectable ammonia. The buffered filtrate containing the urease was then distilled as for ruminal ammonia samples. Urine samples were made alkaline with $\mathrm{NaOH}$ and distilled to remove ammonia, then adjusted to $\mathrm{pH} 6 \cdot 5$ with $\mathrm{H}_{2} \mathrm{SO}_{4}$. Urease was added to hydrolyse urea and the ammonia released was distilled and titrated (as above). 'Total $\mathrm{N}$ in samples of bacteria and faeces and urine was measured by normal Kjeldahl procedures with $\mathrm{NaOH}$ used as the alkaline reagent during steam distillation.

Contamination of the samples with ammonia from the atmosphere during the procedures was shown to be negligible. Particular care was taken in the design of the steam-distillation apparatus so as to minimize contamination between successive samples, and $20 \mathrm{ml}$ ethanol were distilled between samples to remove traces of ammonia which are adsorbed on to the glassware of the distillation apparatus (Bremner, 1965).

Ruminal fluid samples and other samples were taken immediately before isotope was injected and processed at the same time as each batch of experimental samples to give values for normal abundance of $\mathrm{N}$ in the animals.

The gas handling system of the mass spectrometer was designed to allow the storage vial containing the dried sample of ammonium sulphate to be connected and sealed with a neoprene seal. Gases above the sample and through the gas handling system to the analyser tube could be evacuated and background peaks measured before hypobromite was released on to the ammonium sulphate to evolve elemental $\mathrm{N}$ into the evacuated system. This $N$ passed through a fine stainless-steel capillary tube 
immersed in liquid $\mathrm{N}$ in order to trap out contaminants such as the oxides of $\mathrm{N}$ and carbon dioxide before passing into the analyser tube of the mass spectrometer. Calculation of the abundance of ${ }^{15} \mathrm{~N}$ in the $\mathrm{N}$ of the samples was made from the ratio of the mass 28 and 29 peaks after subtraction of the background peaks. These were always less than $\mathbf{I} \%$ of the sample peaks. Correction for 'air' contamination, which was generally negligible under these conditions, was made from the peak at mass 40 . All precautions outlined by Martin \& Ross (1968) were observed. Information on the accuracy of the MSro mass spectrometer used under these conditions is given in the results section.

\section{Mathematical procedure}

The equations for the lines which were fitted to the specific radioactivity and enrichment values obtained at any time for samples taken from a sampled pool were of the general form:

(I) single injection:

$$
\mathrm{SR}_{t} \text { or } \mathrm{E}_{t}=\sum_{i=1}^{n} \mathrm{~A}_{i} e^{-m_{i} t},
$$

(2) continuous infusion:

$$
\mathrm{SR}_{t} \text { or } \mathrm{E}_{t}=\sum_{i=1}^{n} \frac{\mathrm{A}_{i}}{m_{i}}\left(\mathrm{I}-e^{m_{i} t}\right),
$$

where $t=$ time $(\min ), \mathrm{SR}_{t}=$ specific radioactivity $(\mu \mathrm{Ci} / \mathrm{mg}$ urea) of plasma urea at time $t, \mathrm{E}_{t}=$ enrichment of $\mathrm{N}$ in ruminal ammonia or plasma urea (atoms \% excess), $\mathrm{A}=$ zero-time intercept of each exponential component $(\mu \mathrm{Ci} / \mathrm{mg}$ urea or atoms $\%$ excess); $m=$ rate-constant of each component $\left(\min ^{-1}\right), n=$ number of exponential components and $i=$ exponential component identification.

A computer programme was used to obtain the equation for the line which was a good fit to the experimental points obtained for specific radioactivity or enrichment with time in either single injection or continuous infusion experiments. The programme minimized variance by an iterative procedure based on the simplex routine as improved by Nelder \& Mead (1965). The plateau values for specific radioactivity or enrichment at time infinity were predicted using the computer programme to fit a curve with one more exponent than was found to be necessary to describe the curves from single injection experiments made under similar conditions. The rate-constants of the terminal exponents were restrained to be zero, and the corresponding intercepts gave the plateau values.

For curves where all intercepts (A) were positive, variance was calculated as:

$$
\sum\left(\frac{\text { observed value }- \text { expected value }}{\text { expected value }}\right)^{2} \text {. }
$$

If any of the intercepts were negative, variance was calculated as:

$$
\Sigma \text { (observed value - expected value) })^{2} .
$$

Calculations of total entry rate, irreversible loss, recycling and pool size with respect to the sample pool were calculated by standard procedures (see Baker \& Rostami, I969; 
Rescigno \& Segre, 1966; White, Steel, Leng \& Luick, I969). The area under a curve at time infinity $(X)$ was calculated by integrating the equation to the curve, resulting in the formula

$$
X=\sum_{i=1}^{n} \frac{A_{i}}{m_{i}}
$$

The area at time $t\left(X_{t}\right)$ was given by

$$
X_{t}=\sum_{i=1}^{n} \frac{\mathrm{A}_{i}}{m_{i}}\left(\mathrm{I}-e^{-m_{i} t}\right)
$$

\section{RESULTS}

\section{Ammonia absorption from the atmosphere during sample preparation}

An enriched ammonium salt was used to assess the errors in measurements of abundance of ${ }^{15} \mathrm{~N}$ in samples, caused by addition of unlabelled ammonia from the laboratory atmosphere during distillation, titration and evaporation of distillates.

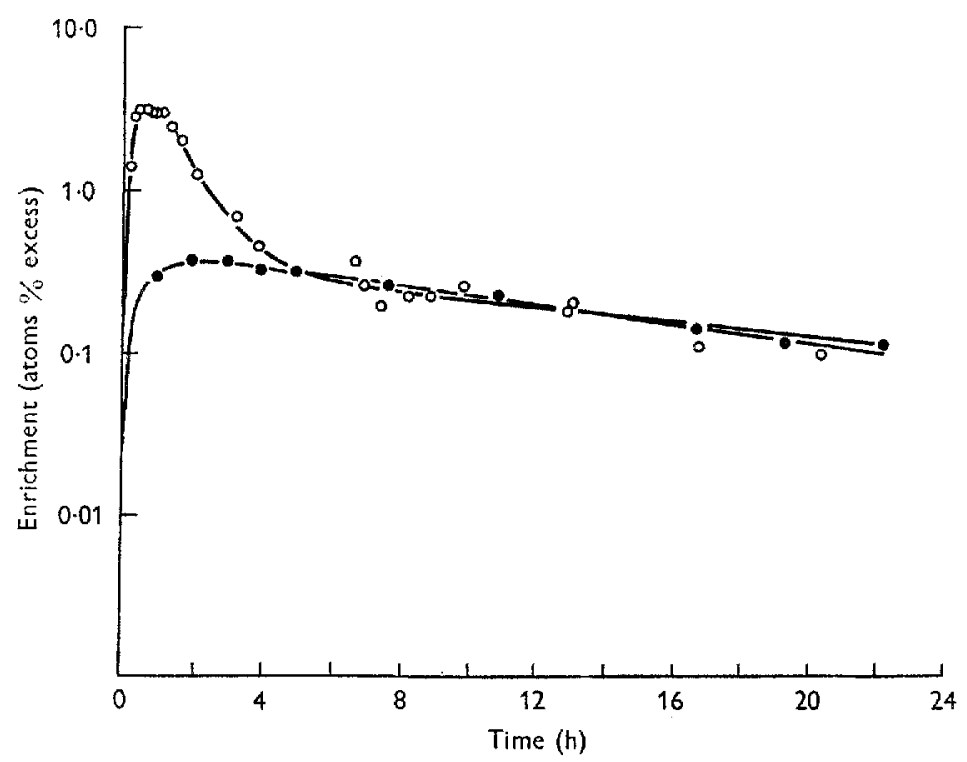

Fig. I. Enrichments of ruminal ammonia $N(O)$ and of plasma urea $N(O)$ with time after a single injection of $\left[{ }^{15} \mathrm{~N}\right]$ ammonium salt given intraruminally to sheep.

Pairs of samples (one of the pair was distilled, titrated and evaporated and the other was untreated) were included at random in sequences of samples analysed for enrichment. The mean value for the abundance of ${ }^{15} \mathrm{~N}$ in five samples $(660 \mu \mathrm{g} \mathrm{N})$ which were distilled was $98 \%$ that for the five samples $(660 \mu \mathrm{g} N)$ which were not distilled. The difference was not significant $(P<0.05)$. These test samples contained less $\mathrm{N}$ than any biological sample, so it was concluded that ammonia $\mathrm{N}$ absorbed during the laboratory procedures had no appreciable effect on the measurements. 


\section{Accuracy and variation in mass spectrometer measurements}

The mean $( \pm \mathrm{SD})$ abundance in samples of $\left(\mathrm{NH}_{4}\right)_{2} \mathrm{SO}_{4}$ (AR grade) estimated on fifty-six occasions during the period of this study (to assess day-to-day variation) was $0.360 \pm 0.003$ atoms $\%$. The mass spectrometer gave accurate measurements of ${ }^{15} \mathrm{~N}$ abundance in the range of $0.37-99$ atoms $\%$ : the relationship between observed abundance measurements and the expected abundance of samples obtained by serial dilution (from $99-0.37$ atoms \%) of the $\mathrm{N}$ in an enriched salt was linear, and the maximum individual deviations from fourteen abundance measurements were $-3 \cdot 3$ and $+\mathrm{I} \cdot 8 \%$ of the expected values.

\section{Single injection of a solution containing $\left[{ }^{15} \mathrm{~N}\right]$ ammonium chloride and $\left[{ }^{51} \mathrm{Cr}\right] \mathrm{EDTA}$ into the rumen}

The enrichment of ammonia $\mathrm{N}$ in the ruminal fluid with time after a single injection of $\left[{ }^{15} \mathrm{~N}\right]$ ammonium chloride into sheep $\mathrm{A}$ is shown in Fig. $\mathrm{I}$. The curve has an initial rising component which is similar to that obtained with $\left[{ }^{51} \mathrm{Cr}\right] \mathrm{EDTA}$, indicating that mixing of isotope was not instantaneous in the ruminal fluid. 'Thereafter, the curve

Table I. Measures of ammonia and urea metabolism in sheep estimated by using single injections $(S I)$ or continuous infusions $(C I)$ of $\left[{ }^{15} \mathrm{~N}\right]$ ammonium salt into the rumen. $\left.{ }^{\left[{ }^{51}\right.} \mathrm{Cr}\right] E D T A$ was also injected to estimate rumen volume

\begin{tabular}{|c|c|c|c|c|c|c|c|c|c|c|c|c|}
\hline \multirow[b]{4}{*}{ Sheep } & \multirow{4}{*}{$\begin{array}{l}\text { Tech- } \\
\text { nique }\end{array}$} & \multirow{4}{*}{$\begin{array}{c}\text { Sheep } \\
\text { weight } \\
\text { (kg) }\end{array}$} & \multirow{4}{*}{$\begin{array}{c}\mathrm{N} \\
\text { intake } \\
(\mathrm{g} / \mathrm{d})\end{array}$} & \multicolumn{7}{|c|}{ Ruminal measurements } & \multirow{2}{*}{\multicolumn{2}{|c|}{$\begin{array}{l}\text { Plasma urea } \\
\text { contributed } \\
\text { by ruminal } \\
\text { ammonia }\end{array}$}} \\
\hline & & & & \multirow{3}{*}{$\begin{array}{l}\text { Fluid } \\
\text { volume } \\
\text { (1) }\end{array}$} & \multirow{3}{*}{$\begin{array}{c}\text { Am- } \\
\text { monia } \\
\text { concen- } \\
\text { tration } \\
\text { (mg N/ } \\
\text { too ml) }\end{array}$} & \multirow{2}{*}{\multicolumn{2}{|c|}{$\begin{array}{c}\text { Pool size } \\
(\mathrm{mg} N)\end{array}$}} & \multirow{3}{*}{$\begin{array}{l}\text { Total } \\
\text { entry } \\
\text { of am- } \\
\text { monia } \\
\text { (g N/d) }\end{array}$} & \multirow{3}{*}{$\begin{array}{c}\text { Irre- } \\
\text { versible } \\
\text { loss } \\
\text { (g N/d) }\end{array}$} & \multirow{3}{*}{$\begin{array}{c}\text { Re- } \\
\text { cycling } \\
(\mathrm{g} N / \mathrm{d})\end{array}$} & & \\
\hline & & & & & & & & & & & \multirow{2}{*}{$\begin{array}{l}3 \mathrm{~h} \\
(\%)\end{array}$} & \multirow{2}{*}{$\begin{array}{c}\text { Plateau } \\
\text { value* } \\
(\%)\end{array}$} \\
\hline & & & & & & {$\left[{ }^{51} \mathrm{Cr}\right]$} & {$\left[{ }^{15} \mathrm{~N}\right]$} & & & & & \\
\hline A & SI & $36 \cdot 3$ & $22 \cdot 5$ & $3 \cdot 25$ & $17 \cdot 3$ & 559 & $6_{3} 8$ & $17 \cdot 2$ & $1 \mathrm{I} \cdot 2$ & $6 \cdot 0$ & 14 & 53 \\
\hline B & SI & $36 \cdot 7$ & $22 \cdot 5$ & $2 \cdot 30$ & $17 \cdot 5$ & $42 I$ & 470 & I I $\cdot 2$ & $8 \cdot 0$ & $3 \cdot 2$ & 8 & $4 I$ \\
\hline $\mathrm{E}$ & CI & $35 \cdot 7$ & 23.0 & $2 \cdot 98$ & $29 \cdot 0$ & 864 & - & - & I I. 4 & - & - & 46 \\
\hline$F$ & CI & $32 \cdot 6$ & $23 \cdot 0$ & $3 \cdot 76$ & $25 \cdot 9$ & 974 & 一 & $\cdots$ & $9 \cdot I$ & - & 15 & $3^{8}$ \\
\hline Mean & & $35 \cdot 3$ & $22 \cdot 8$ & 3.07 & $22 \cdot 4$ & 705 & 555 & $14 \cdot 2$ & $9 \cdot 9$ & $4 \cdot 3$ & 12 & 45 \\
\hline $\mathrm{SE}$ & & 0.9 & 0.2 & 0.31 & 3.0 & 129 & 59 & $2 \cdot I$ & 0.8 & $I \cdot 4$ & $2 \cdot 2$ & $3 \cdot 3$ \\
\hline
\end{tabular}

$\left[{ }^{51} \mathrm{Cr}\right]$ measurement made from volume of distribution of $\left[{ }^{51} \mathrm{Cr}\right]$ EDTA and ruminal ammonia concentration.

$\left[{ }^{15} \mathrm{~N}\right]$ measurement made by compartmental analysis of ${ }^{25} \mathrm{NH}_{4}{ }^{+}$isotope dilution values.

* At time infinity.

was well described by an equation which had two exponential components, one describing the rapid decline in enrichment between about $\mathrm{x}$ and $5 \mathrm{~h}$ after injection, and the other describing the slower decline in enrichment from 5 to $2 \mathrm{I} \mathrm{h}$. The latter two components were considered and formulas (see Baker, Shipley, Clark \& Incefy, 1959; White et al. 1969) were used to calculate the size of the ammonia pool sampled in the rumen, and the total entry rate, irreversible loss and recycling rate of ammonia (see Table 1). The $\left[{ }^{51} \mathrm{Cr}\right]$ EDTA space has been used with the ruminal ammonia 
concentration to give an alternative method for estimating the size of the ruminal ammonia pool (Table $\mathbf{r}$ ).

The appearance of enriched urea in plasma during the $22 \mathrm{~h}$ following the injection was well described by a curve with two exponential components. The ratio of the area under the appearance curve for plasma $\left[{ }^{15} \mathrm{~N}\right]$ urea to the area under the disappearance curve for $\left[{ }^{15} \mathrm{~N}\right] \mathrm{ammonia}$ (Fig. $\mathrm{x}$ ), obtained by integration, gave the proportion of the urea $\mathrm{N}$ contributed by ruminal ammonia (Table $\mathrm{r}$ ). This ratio increased from about $\mathrm{I} \mathrm{x} \%, 3 \mathrm{~h}$ after injection, to about $45 \%$ after $24 \mathrm{~h}$ (Fig. $\mathrm{r}$ ). The quantity of

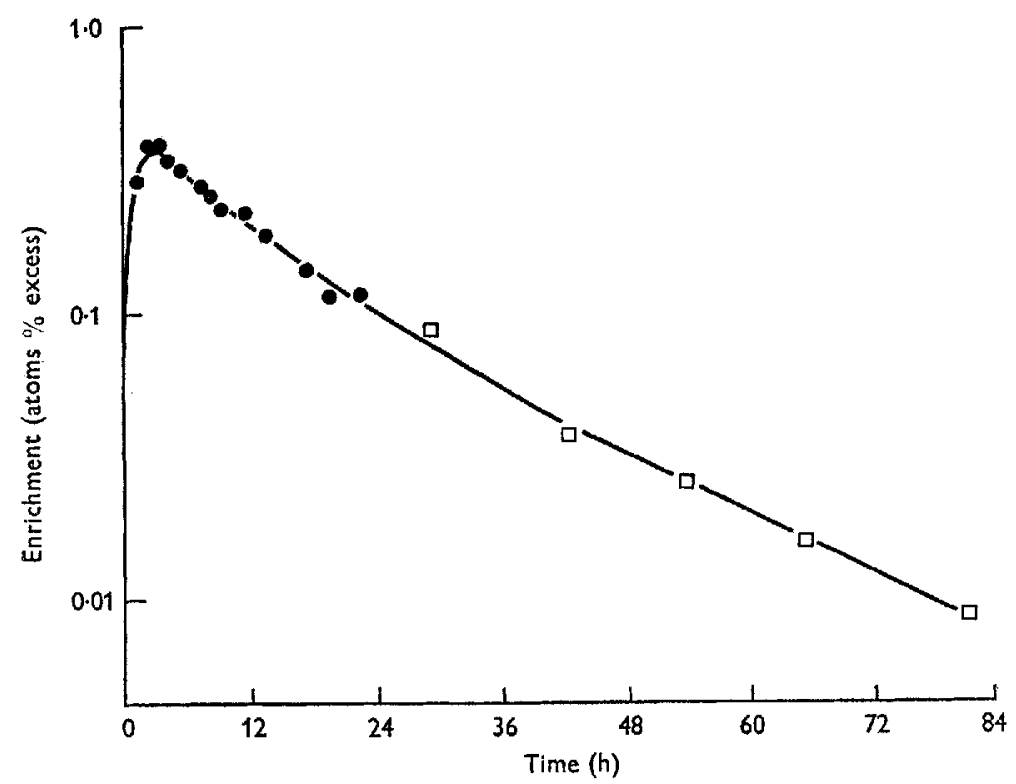

Fig. 2. Enrichments of plasma urea $N(\bullet)$ and urinary urea $N(\square)$ with time after a single injection of $\left[{ }^{15} \mathrm{~N}\right]$ ammonium salt given intraruminally to sheep.

$\mathrm{N}$ from ruminal ammonia being synthesized into urea at 3 and $24 \mathrm{~h}$ was then calculated (see p. r89) from the estimates of urea synthesis. When the curve for enrichment of plasma urea was followed between $2 \mathrm{I}$ and $80 \mathrm{~h}$ after the injection, further slow exponential components became evident (Fig. 2). Only $26 \%$ of the ${ }^{15} \mathrm{~N}$ in $\left[{ }^{15} \mathrm{~N}\right] \mathrm{am}-$ monium chloride injected into the rumen was excreted in urinary urea during the $24 \mathrm{~h}$ following the injection.

\section{Continuous infusion of $\left[{ }^{15} \mathrm{~N}\right]$ ammonium sulphate into the rumen}

The enrichment of ammonia $\mathrm{N}$ in the ruminal fluid with time after the commencement of a continuous infusion of $\left[{ }^{15} \mathrm{~N}\right] \mathrm{ammonium}$ sulphate into sheep $\mathrm{H}$ is given in Fig. 3. The experimental results were well described by a curve with two exponential components and the plateau at time infinity was predicted by using a computer programme (see p. I8r).

The corresponding curve for the appearance of enriched plasma urea $\mathrm{N}$ is also given in Fig. 3. The ratio of ruminal ammonia enrichment to that of plasma urea en- 
richment at time infinity gave the proportion of the urea synthesis arising from ruminal ammonia $N$ and the quantity of ruminal ammonia $N$ involved in plasma urea synthesis was calculated (Table 2; see p. I89).

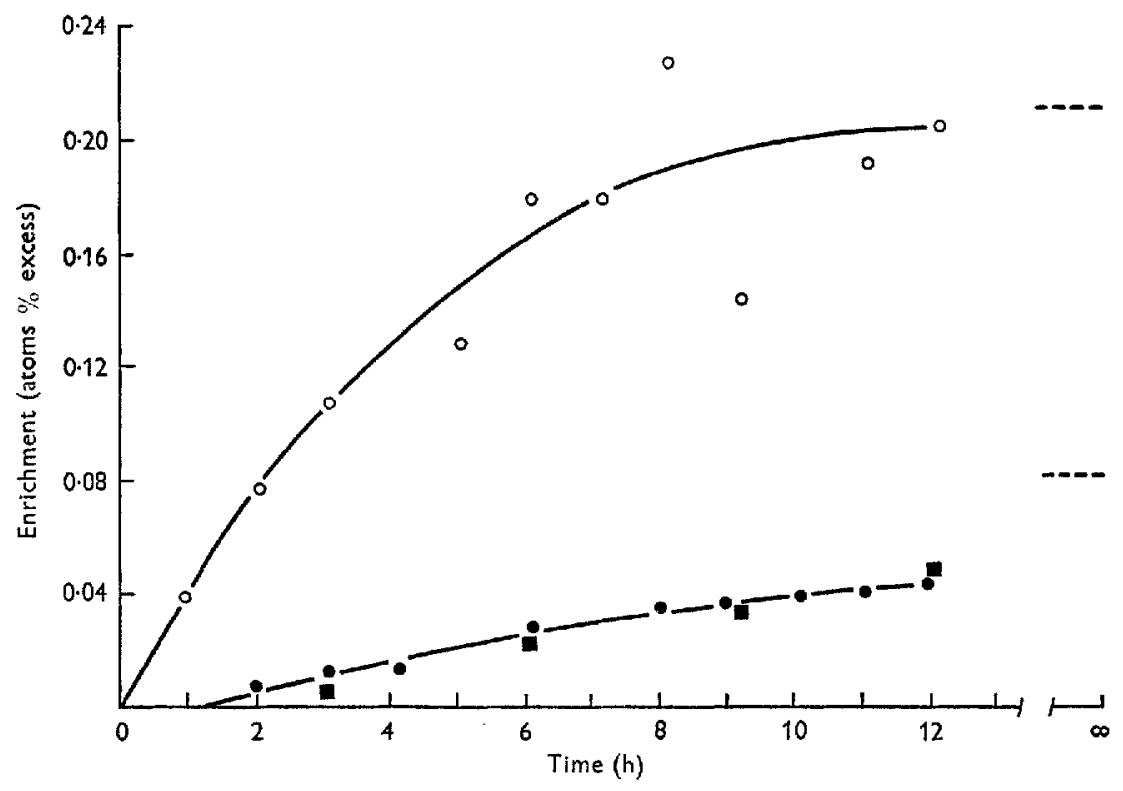

Fig. 3. Enrichments of ruminal ammonia $N(O)$, plasma urea $N(\bullet)$ and ruminal bacterial $N$

(a) during a continuous infusion of $\left[{ }^{55} \mathrm{~N}\right]$ ammonium salt given intraruminally to sheep.

The broken lines indicate the predicted enrichments at time infinity.

Table 2. Measures of urea metabolism in sheep estimated by using single injections (SI) or continuous infusions $(\mathrm{CI})$ of $\left[{ }^{14} \mathrm{C}\right]$ urea into the blood. These measurements were obtained at the same time as those of the ammonia pool in the rumen (Table $\mathrm{I}$ )

\begin{tabular}{|c|c|c|c|c|c|c|c|}
\hline Sheep & Technique & $\begin{array}{l}\text { Body urea } \\
N \text { pool } \\
\text { size }(g) \\
{\left[{ }^{14} \mathrm{C}\right]}\end{array}$ & $\begin{array}{l}\text { Urea con- } \\
\text { centration } \\
(\mathrm{mg} \mathrm{N} / \\
\text { 100 } \mathrm{ml})\end{array}$ & $\begin{array}{l}\text { Body urea } \\
\text { space (l) } \\
{\left[{ }^{14} \mathrm{C}\right]}\end{array}$ & $\begin{array}{c}\text { Urea } \\
\text { irreversibly } \\
\text { lost }(\mathrm{g} \mathrm{N} / \mathrm{d}) \\
{\left[{ }^{14} \mathrm{C}\right]}\end{array}$ & $\begin{array}{l}\text { Urea } \\
\text { excretion } \\
(\mathrm{g} \mathrm{N} / \mathrm{d})\end{array}$ & $\begin{array}{c}\text { Urea } \\
\text { degradation } \\
\text { (g N/d) } \\
{\left[{ }^{14} \mathrm{C}\right]}\end{array}$ \\
\hline A & SI & 4.4 & $23 \cdot 9$ & $18 \cdot 5$ & 15.8 & $8 \cdot 2$ & $7 \cdot 6$ \\
\hline B & SI & $3 \cdot 6$ & $19^{\circ} 0$ & $18 \cdot 7$ & $14^{\cdot I}$ & $7 \cdot 2$ & $6 \cdot 9$ \\
\hline $\mathrm{E}$ & CI & 一 & $23 \cdot 2$ & - & $15 \cdot 7$ & 13.8 & 1.9 \\
\hline $\mathrm{F}$ & CI & - & 29.5 & - & 20.0 & $14 \cdot I$ & 5.9 \\
\hline Mean & & 4.0 & $23 \cdot 9$ & $18 \cdot 6$ & 16.4 & 10.8 & $5 \cdot 6$ \\
\hline SE & & 0.3 & $2 \cdot 2$ & $0 . \mathrm{I}$ & $\mathrm{I} \cdot 3$ & $\mathrm{I} \cdot 8$ & $x \cdot 3$ \\
\hline
\end{tabular}

$\left[{ }^{14} \mathrm{C}\right]$ estimated from ${ }^{14} \mathrm{C}$ isotope dilution values.

Single injection of $\left[{ }^{15} \mathrm{~N}\right]$ urea and $\left[{ }^{14} \mathrm{C}\right]$ urea given together intravenously

The enrichment of plasma urea $\mathrm{N}$ with time after a single intravenous injection of $\left.{ }^{15} \mathrm{~N}\right]$ urea into sheep $\mathrm{C}$ is given in Fig. 4 . The experimental results were well described by a curve with three exponential components. However, in the curve obtained for sheep D, no third exponential component was apparent during the $24 \mathrm{~h}$ following the injection of $\left[{ }^{15} \mathrm{~N}\right]$ urea. The curve for the decline in specific radioactivity 
of $\left[{ }^{14} \mathrm{C}\right]$ urea in plasma following the single injection of $\left[{ }^{14} \mathrm{C}\right]$ urea is given in Fig. 4 as a comparison with the corresponding curve obtained with $\left[{ }^{15} \mathrm{~N}\right]$ urea. The results for specific radioactivity were well described by a curve with two exponential components.

The curve for the appearance of enriched ammonia $\mathrm{N}$ in the rumen following the single intravenous injection of $\left[{ }^{15} \mathrm{~N}\right] \mathrm{urea}$ is also given in Fig. 4 and a good fit to the
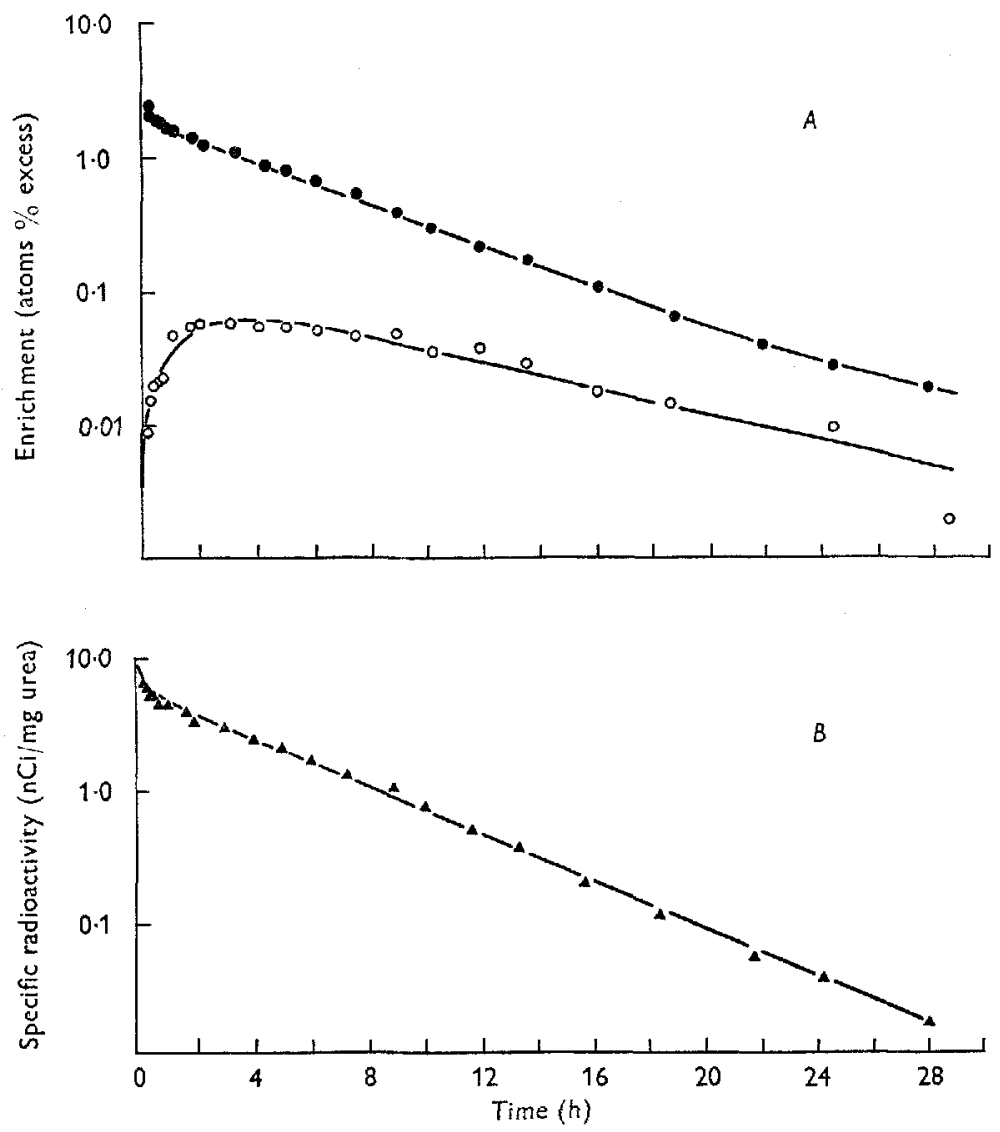

Fig. 4. (A) Enrichments of plasma urea $N(C)$ and ruminal ammonia $N(O)$, and $(B)$ the specific radioactivity of plasma urea $(\triangle)$, with time after a single injection of a mixture of $\left[{ }^{15} \mathrm{~N}\right]$ urea and $\left[{ }^{14} \mathrm{C}\right]$ urea given intravenously to sheep.

experimental results was obtained by a curve with two exponential components. The ratio of the area under this curve, obtained by integration, to the area under the curve describing the decline in plasma urea $\mathrm{N}$ enrichment gave the proportion of ruminal ammonia $\mathrm{N}$ entry which was derived from plasma urea (Table 3 ). In sheep $\mathrm{D}$, the proportion of faecal total $\mathrm{N}$ derived from plasma urea $(2.5 \%)$ was obtained from the areas under the plasma urea and faecal total $\mathrm{N}$ curves, and the quantity of faecal total $\mathrm{N}$ being derived from plasma urea $\left(\mathrm{O}^{\circ} \mathrm{I} \mathrm{g} \mathrm{N} / \mathrm{d}\right)$ was $2 \%$ of the rate of faecal $\mathrm{N}$ excretion $(4.7 \mathrm{~g} \mathrm{~N} / \mathrm{d})$. 


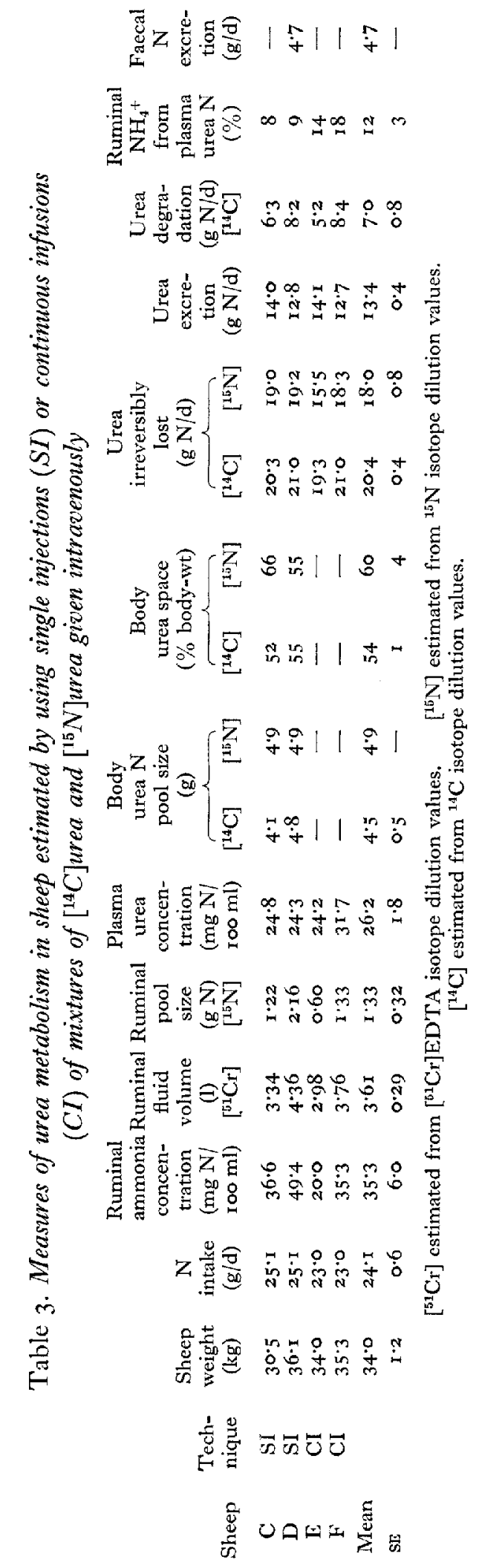


Continuous infusion of $\left[{ }^{15} \mathrm{~N}\right]$ urea and $\left[{ }^{14} \mathrm{C}\right]$ urea given together intravenously

The enrichments in plasma urea $\mathrm{N}$ and ruminal ammonia $\mathrm{N}$ with time after the commencement of infusion into sheep $\mathrm{G}$ are given in Fig. 5. Both sets of experimental results were well described by curves with two exponential components. The plateau enrichments were predicted (see p. 181). The ratio of these plateau enrichments at time infinity gave the proportion of ammonia entering the ruminal ammonia pool which was derived from plasma urea $\mathrm{N}$ (Table 3 ). The ammonia entering the ruminal
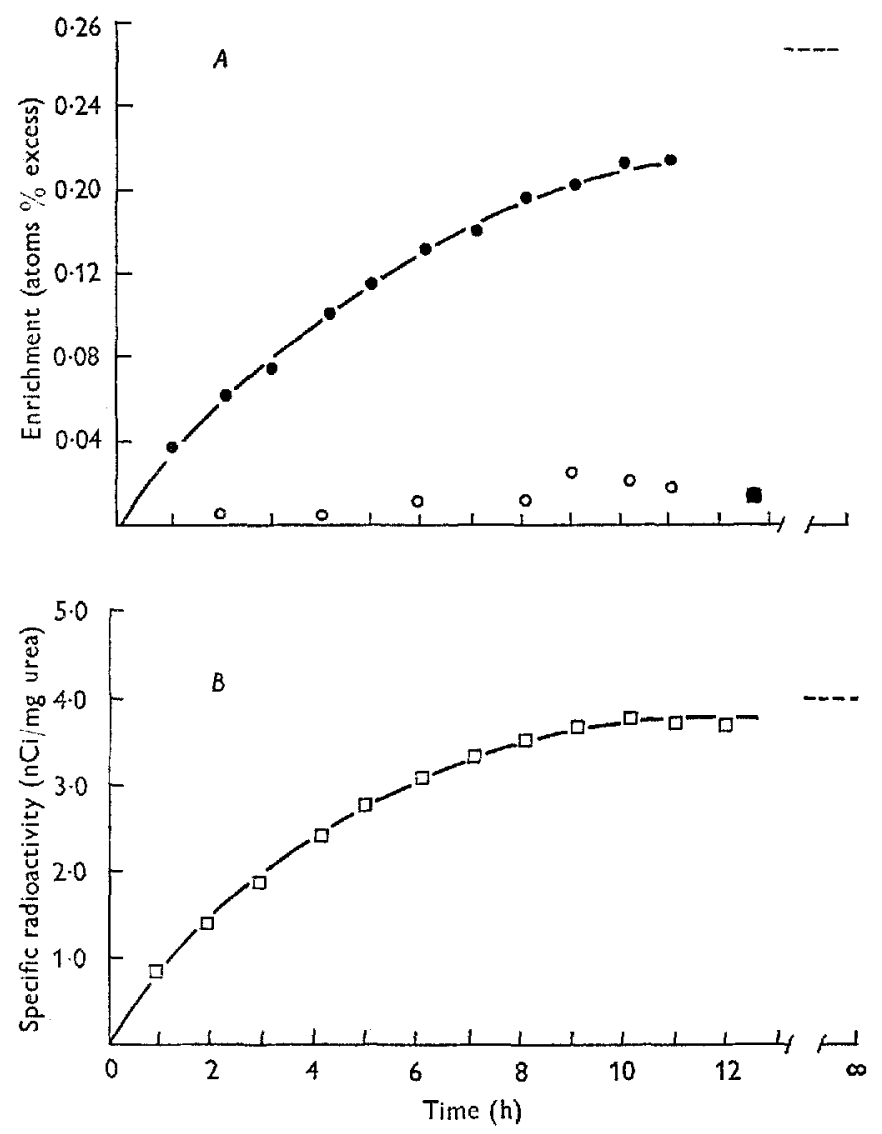

Fig. 5. (A) Enrichments of plasma urea $\mathrm{N}(\bullet)$, ruminal ammonia $\mathrm{N}(O)$ and ruminal bacterial $\mathbf{N}(\mathbf{\square})$, and $(B)$ specific radioactivity of plasma urea $(\square)$, during a continuous infusion of a mixture of $\left[{ }^{15 N}\right]$ urea and $\left[{ }^{14} \mathrm{C}\right]$ urea given intravenously to sheep. The broken lines indicate the predicted enrichment or specific radioactivity at time infinity.

ammonia pool which was derived from plasma urea could then be calculated (see p. I89). Some of the urea $\mathrm{N}$ returned to the rumen was incorporated into the bacterial $\mathrm{N}$ fractions as indicated by the appearance of enriched $\mathrm{N}$ in bacterial samples isolated from the rumen contents (Fig. 5). In Fig. 5 the specific radioactivity with time during a continuous infusion of $\left[{ }^{14} \mathrm{C}\right]$ urea is also shown. 


\section{Irreversible loss of urea estimated with ${ }^{14} \mathrm{C}$ and ${ }^{15} \mathrm{~N}$ isotopes}

Irreversible loss of $\left[{ }^{14} \mathrm{C}\right]$ urea and $\left[{ }^{15} \mathrm{~N}\right]$ urea from the sampled pool of urea has been measured in sheep $C, D, E$ and $F$ by injections of a solution containing $\left[{ }^{14} \mathrm{C}\right]$ urea and $\left[{ }^{15} \mathrm{~N}\right]$ urea (Table 2). The irreversible loss of $\left[{ }^{15} \mathrm{~N}\right]$ urea was significantly lower (mean $12 \%$ ) in all instances than the corresponding loss of $\left[{ }^{14} \mathrm{C}\right]$ urea in the same sheep $(P<0.05)$.

\section{Estimates of the flows of $N$}

Using mean values from experiments where $\left[{ }^{15} \mathrm{~N}\right] \mathrm{ammonia}$ or $\left[{ }^{15} \mathrm{~N}\right] \mathrm{urea}$ was used, the following calculations were made:

(1) The irreversible loss of urea from plasma $=18.4 \pm 0.9 \mathrm{~g} \mathrm{~N} / \mathrm{d}$ (Tables 2,3 ).

(2) The irreversible loss of ruminal ammonia $=9.9 \pm 0.8 \mathrm{~g} \mathrm{~N} / \mathrm{d}$ (Table I).

(3) The proportion of ruminal ammonia derived from plasma urea $\mathrm{N}=12 \%$ (Table 3 ).

(4) The proportion of plasma urea derived from ruminal ammonia $\mathrm{N}$ (Table 1): (a) at $3 \mathrm{~h}=\mathrm{rI} \%,(b)$ at time infinity $=45 \%$.

(5) The rate of transfer of plasma urea $N$ to ruminal ammonia $N=(2) \times(3)=$ $\mathrm{r} \cdot 2 \mathrm{~g} \mathrm{~N} / \mathrm{d}$.

(6) The rate of transfer of ruminal ammonia $\mathrm{N}$ to plasma urea $\mathrm{N}$ : (i) at $3 \mathrm{~h}=$ (I) $\times(4 a)=2 \cdot 0 \mathrm{~g} \mathrm{~N} / \mathrm{d}$, (ii) at time infinity $=(\mathrm{I}) \times(4 b)=8 \cdot \mathrm{I} \mathrm{g} \mathrm{N} / \mathrm{d}$.

\section{DISCUSSION}

The pathways of ammonia, amino acid and urea metabolism have been incorporated into a model shown in Fig. 6. For convenience, the digestive tract has been divided into three areas: (I) the anterior area of microbial colonization (i.e. the reticulorumen), (2) the abomasum, duodenum, jejunum and anterior ileum, and (3) the major areas of microbial colonization in the lower digestive tract (i.e. lower ileum, caecum and large bowel). The pools of $\mathrm{N}$ in the digestive tract are considered separately from the pools of ammonia, urea and amino acids in the body, which are considered separately from the larger pools with slower turn-over rates such as the muscle proteins and structural proteins. Pathways which are believed to be the major routes for conversion of one nitrogenous compound into another are shown and, where possible, estimates of the flow of $\mathrm{N}$ have been made.

A fundamental assumption necessary for the kinetic appraisal of the isotope dilution results reported here is that the system described in Fig. 6 was in a steady state, i.e. the compartment sizes and turn-over rates remained constant during the experimental period. Under the hourly-feeding conditions used, fairly constant concentrations of ammonia in ruminal fluid and urea in plasma were obtained, indicating that these conditions were largely fulfilled. The sheep had been given their diet for at least 3 months before these experiments and were maintaining a constant body-weight, and they were assumed to be in $\mathrm{N}$ equilibrium.

In these studies, approximately $60 \%$ of the dietary $\mathrm{N}$ was digested in the rumen. By comparison, Pilgrim, Gray, Weller \& Belling (1970) estimated that $48-59 \%$ of the N 
in a lucerne diet given to a sheep was digested in the rumen. Most of the dietary $\mathrm{N}$ escaping digestion in the rumen may have been digested and absorbed in the lower digestive tract, as it has been reported that most of the $\mathrm{N}$ in faeces of sheep is of bacterial origin (Mason, 1969).

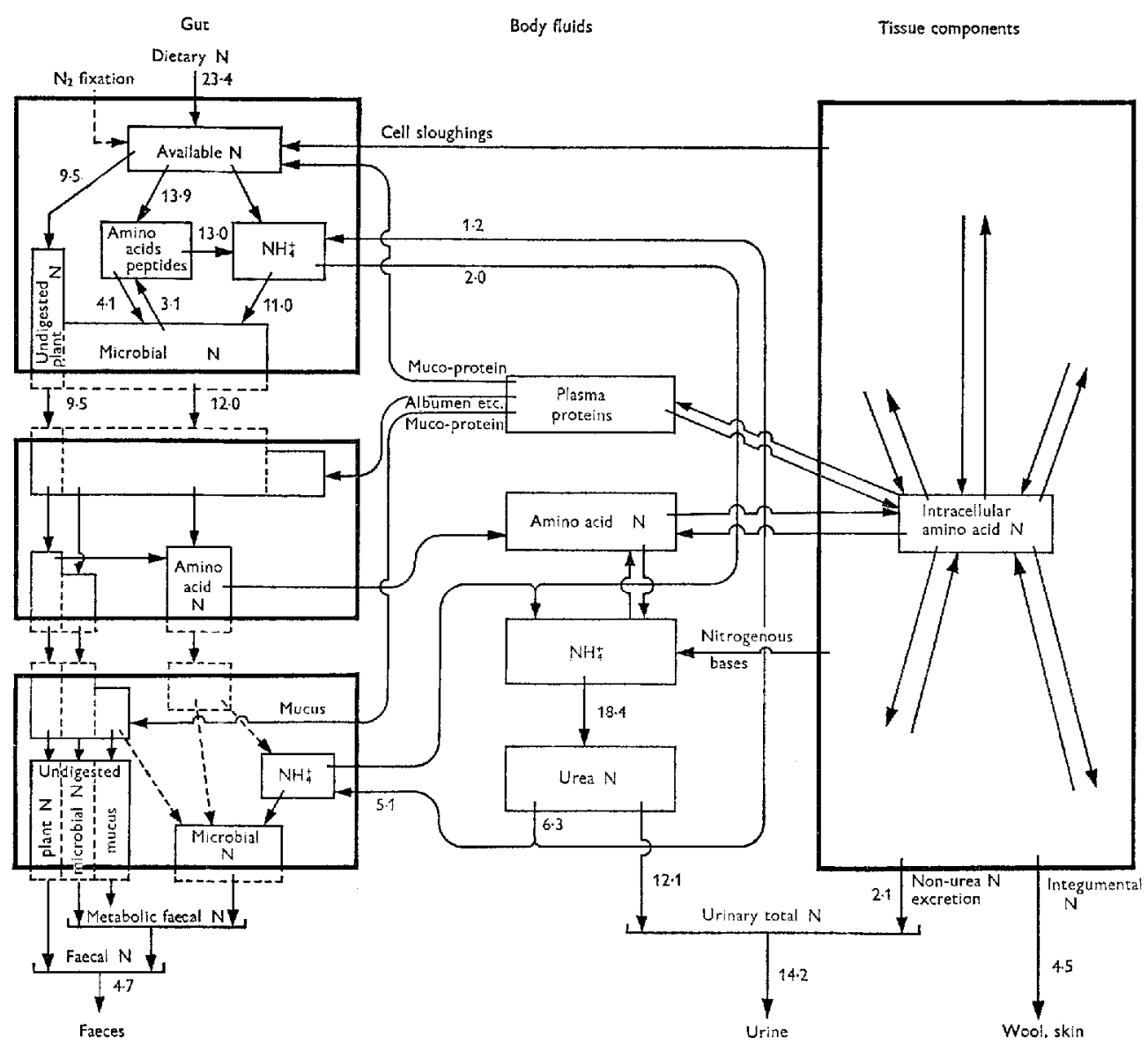

Fig. 6. A model of nitrogen metabolism in sheep showing the movement of nitrogen ( $\mathrm{g} \mathrm{N} / \mathrm{d}$ ) between the various nitrogenous pools in the body.

The $\mathrm{N}$ of compounds digested in the rumen which did not cnter the ruminal ammonia pool must have been lost from the rumen in nitrogenous compounds more complex than ammonia. This could occur, for instance, by uptake of peptides and amino acids (Portugal, r963; Portugal \& Sutherland, r966; Wright \& Hungate, I967; Coleman, 1967 ) or by absorption of free amino acids across the rumen wall (Demaux, Le Bars, Mollé, Rérat \& Simonnet, 1961; Cook, Brown \& Davis, 1965), but the latter was assumed to be quantitatively insignificant.

Ammonia is irreversibly lost from the rumen $(a)$ by incorporation into microbial cells which pass to the abomasum, $(b)$ by direct absorption through the rumen wall 
into portal blood, and $(c)$ by loss in fluid entering the abomasum. Ammonia entering the abomasum is probably absorbed when it reaches the intestinal contents (Smith, I969) and in our experiments this fraction was considered to be part of the $2 \mathrm{~g} \mathrm{~N} / \mathrm{d}$ being absorbed as ammonia into the portal blood. The remainder of the ammonia $\mathrm{N}$ being irreversibly lost from the rumen $(7.9 \mathrm{~g} \mathrm{~N} / \mathrm{d})$ was therefore largely lost in microbial cells leaving the rumen.

Of the calculated incorporation of $\mathrm{N}$ into microbial cells, approximately $80 \%$ was derived from ammonia and $20 \%$ was derived from amino acids (Fig. 6). Pilgrim et al. (r970) estimated that 62 and $64 \%$ of the bacterial protein and 35 and $41 \%$ of the protozoal protein were derived from ruminal ammonia in sheep given a lucerne diet. If it is assumed that a greater quantity of bacterial cells becomes available to the animal, then it is necessary to postulate that a greater proportion of the $\mathrm{N}$ of bacterial cells comes directly from the ruminal amino acid pool. If the estimates of the proportion of bacterial protein derived from ruminal ammonia (Pilgrim et al. 1970 ) are taken, the amount of bacterial protein available to the host animal would be increased to I $7 \mathrm{~g} \mathrm{~N} / \mathrm{d}$. It appears that the uptake of amino acid makes an appreciable contribution to microbial synthesis in sheep given lucerne diets.

The mean rate of recycling of ammonia to the ruminal ammonia pool was $4.3 \mathrm{~g} \mathrm{~N} / \mathrm{d}$. The recycling takes place largely within the rumen itself (see p. 19o), namely, ammonia $\rightarrow$ other nitrogenous compounds $\rightarrow$ ammonia. This could occur either as a result of lysis of viable bacteria in the rumen due to bacteriophage activity (Adams, Gazaway, Brailsford, Hartman \& Jacobson, I966; Hoogenraad, Hird, Holmes \& Millis, 1967) or the engulfment of bacteria by protozoa which utilize bacterial amino acids (Coleman, 1967) and produce ammonia as an end-product of their intermediary metabolism (McDonald, 1968) or from death of bacteria (Hungate, 1967). These results suggest that $30 \%$ of the ammonia continually being incorporated into ruminal protein may have recycled through the amino acid and ammonia pools; one estimate has indicated that $40 \%$ of ruminal bacteria may be engulfed by protozoa (Abe $\&$ Kandatsu, I 969 ). It was assumed that most of the ammonia $\mathrm{N}$ which recycled did so through the amino acid pool (Fig. 6). If this occurs on all diets it may be an important process in supplying the requirements for amino acids and branched-chain fatty acids for some species of bacteria in the rumen. However, if this apparent degradation of micro-organisms could be prevented, it might be one means of increasing the quantity of protein leaving the rumen and available for digestion.

The urea irreversibly lost from plasma (as estimated by using $\left[{ }^{14} \mathrm{C}\right]$ urea) and not excreted in urine $(6.3 \mathrm{~g} \mathrm{~N} / \mathrm{d}$ ) was assumed to enter the digestive tract since this appears to be the only site of urea degradation in the animal. However, only $\mathrm{I} \cdot 2 \mathrm{~g} \mathrm{~N} / \mathrm{d}$ from the mean entry to the digestive tract of $6.3 \mathrm{~g} \mathrm{~N} / \mathrm{d}$ apparently entered the ruminal ammonia pool.

This is a striking result in view of the assumption (von Engelhardt \& Nickel, 1965; Waldo, 1968) that all urea degradation in the body occurs in the rumen or of estimates made by other workers (Juhász, 1965; Egan, 1965; Egan \& Moir, 1965; Weston \& Hogan, 1967; Houpt \& Houpt, 1969) of transfer of greater quantities of urea to the rumen. A possible explanation for the small rate of apparent degradation of the urea 
in the rumen relative to the total degradation rate of urea may involve the conversion of urea into ammonia in the rumen epithelium (Houpt, 1970) and since the concentration gradient for ammonia would be in the direction of blood this ammonia might be reabsorbed without entering the rumen. However, in similar sheep given a similar diet, the differences in concentration of urea in the arterial and venous blood of the rumen were found to be not significant and less than $\mathrm{I} g / \mathrm{d}$ urea $\mathrm{N}$ was estimated to have left the blood draining the rumen (Hecker \& Nolan, r97I). These studies together with the present studies suggest that the major proportion of the urea degradation occurs distal to the rumen.

The quantity of urea appearing as ruminal ammonia could have been completely accounted for by a total salivary flow of $81 / \mathrm{d}$ assuming that the concentration of urea in mixed salivary secretions was $60 \%$ of that in plasma (Somers, I96r). Under the conditions of these studies, it seems unlikely that appreciable quantities of urea were returned to ruminal contents by passage across the rumen wall.

There is some evidence for incomplete hydrolysis of urea entering the rumen, based on the finding that less than $25 \%$ of an injection of $\left[{ }^{14} \mathrm{C}\right]$ urea into the rumen was recovered as ${ }^{14} \mathrm{CO}_{2}$ in respired gases (Farlin, Brown \& Garrigus, 1968), suggesting that urea $\mathrm{N}$ may be incorporated into nitrogenous compounds in the rumen without entering the ruminal ammonia pool. However, there was no evidence of direct incorporation into bacteria of urea breakdown products more complex than ammonia since the enrichment of bacterial $\mathrm{N}$ in the rumen was not greater than the enrichment of ruminal ammonia $\mathrm{N}$ at the same time (Fig. 5).

Some urea may have been returned to the lower digestive tract and degraded or fixed, or both, by hind-gut micro-organisms (Thornton, Bird, Somers \& Moir, r970). After an intravenous dose of $\left[{ }^{15} \mathrm{~N}\right]$ urea only a small proportion $(2 \%)$ of the ${ }^{15} \mathrm{~N}$ had appeared in faecal $\mathrm{N}$ after $3 \mathrm{~d}$ and only $0^{\circ} \mathrm{I} \mathrm{g} \mathrm{N} / \mathrm{d}$ of faecal $\mathrm{N}$ was derived from plasma urea. If appreciable quantities of endogenous urea $N$ were being taken up by microorganisms in the large intestine, it seems necessary to postulate that the resulting microbial cells produced were also degraded and the products absorbed from this organ. Absorption of amino acids from the caecum has been shown (Demaux et al. I96I), but secretions capable of hydrolysing microbial protein have not been reported. However, it does seem possible that lysis and digestion of micro-organisms might occur in the caecum in a way similar to that which has been suggested for the rumen.

To obtain estimates of the quantity of degraded urea $N$ which was resynthesized into urea, estimates of the irreversible loss of urea from plasma as measured by using $\left[{ }^{14} \mathrm{C}\right]$ urea and $\left[{ }^{15} \mathrm{~N}\right]$ urea simultaneously were made (Table 2 ). The quantity of ${ }^{14} \mathrm{C}$ from degraded $\left[{ }^{14} \mathrm{C}\right]$ urea which can be reincorporated into urea appears to be insignificant because of the rapid dilution of $\mathrm{CO}_{2}$ in the bicarbonate pool in the body, which has a very rapid turn-over. The irreversible loss of urea estimated with this isotope is thus a measure of total synthesis of urea entering plasma. The irreversible loss of urea measured simultaneously with $\left[{ }^{15} \mathrm{~N}\right]$ urea was lower $(P<0.05)$ owing to resynthesis of urea from degraded urea $\mathrm{N}$. The differences in irreversible loss of urea $(2.4 \mathrm{~g} \mathrm{~N} / \mathrm{d})$ as measured by using $\left[{ }^{14} \mathrm{C}\right]$ urea and $\left[{ }^{15} \mathrm{~N}\right]$ urea suggests that only $38 \%$ of the urea entering the digestive tract and degraded actually re-enters the urea pool 
(Table 2). This leaves a total quantity of approximately $3.8 \mathrm{~g} \mathrm{~N}$ (after accounting for the fixation of urea $\mathrm{N}$ ) that enters the digestive tract and does not reappear as urea. An explanation appears to be that some of the absorbed ammonia enters nitrogenous compounds (such as amides or non-essential amino acids in the intestinal wall or liver), which are then incorporated into slowly equilibrating pools of $\mathrm{N}$ in, say, body protein. This is consistent with the results of studies in which the ${ }^{15} \mathrm{~N}$ of $\left[{ }^{15} \mathrm{~N}\right]$ ammonium acetate injected intravenously into human subjects appeared extensively in serum and muscle proteins (Fürst, Jonsson, Josephson \& Vinnars, 1970). The degradation of plasma urea in the digestive tract appears to be a mechanism which continuously makes ammonia available for synthesis of nitrogenous compounds in the intestinal wall and the liver. The exponential components which became apparent in the plasma and urine urea enrichment curves (Fig. 2) after $24 \mathrm{~h}$ indicated that ${ }^{15} \mathrm{~N}$ was incorporated into such slowly equilibrating pools. The relatively small proportion $(26 \%)$ of the ${ }^{15} \mathrm{~N}$ given as a single injection of $\left[{ }^{15} \mathrm{~N}\right] \mathrm{ammonium}$ salt into the rumen that was excreted in urinary urea over $24 \mathrm{~h}$ is additional evidence for the incorporation of ammonia $\mathrm{N}$ into body components.

The values in the model presented here are preliminary; however, there are several striking differences between some aspects of the model reported here and other published findings. We have shown with $\left[{ }^{15} \mathrm{~N}\right]$ urea that plasma urea $\mathrm{N}$ returned to the rumen was incorporated into rumen bacteria, but the quantity of urea returned to the rumen $(\mathrm{I} \cdot 2 \mathrm{~g} \mathrm{~N} / \mathrm{d}$ ) was small in relation to assumptions or estimates made by other workers (see Waldo, I968; Smith, 1969). It appears probable that the rest of the alimentary tract may be a more important site of urea degradation in ruminants than has previously been suggested. It appears likely that, in sheep given lucerne diets, considerable quantities of microbial protein may be synthesized in the rumen from amino acids as well as from ammonia (see also Pilgrim et al. 1970) and there was evidence of breakdown of microbial cells within the rumen.

The model described is being further developed to obtain values for ruminants under a variety of dietary conditions and, in particular, studies are being made with animals given low-protein diets.

We are indebted to the Australian Meat Research Committee, the Australian Wool Research Committee and the University of New England for financial support for this project. The skilled technical assistance of Mr F. M. Ball is also gratefully acknowledged.

\section{REFERENCES}

Abe, M. \& Kandatsu, M. (r969). Fap. J. zootech. Sci. 40, 313 .

Adams, J. C., Gazaway, J. A. Jr, Brailsford, M. D., Hartman, P. A. \& Jacobson, N. L. (1966). Experientia 22, 717 .

Baker, N. \& Rostami, H. (1969). F. Lipid Res, 1o, 83 .

Baker, N., Shipley, R. A., Clark, R. E. \& Incefy, G. E. (1959). Am. F. Physiol. I96, 245.

Bloomfield, R. A. ( т $96 \mathrm{r}$ ). Diss. Abstr, 21, 2455.

Bremner, J. M. (1965). In Methods of Soil Analysis [C. A. Black, D. D. Evans, J. L. White, L. E. Ensminger and F. E. Clark, editors]. Agronomy 9, I I 49.

Coleman, G. S. (1967). F. gen. Microbiol. 47, 449.

Cook, R. M., Brown, R. E. \& Davis, C. L. (1965). F. Dairy Sci. 48, 475. 
Demaux, G., Le Bars, H., Mollé, J., Rérat, A. \& Simonnet, H. (196r). Bull. Acad. vét. Fr. 34, 85.

Egan, A. R. (1965). Aust. F. agric. Res. 16, 463 .

Egan, A. R. \& Moir, R. (1965). Aust. F. agric. Res. 16, 437.

el-Shazly, K. (1952). Biochem. F. 51, 640.

Farlin, S. D., Brown, R. E. \& Garrigus, U. S. (1968). F. Anim. Sci. 27, 771.

Fürst, P., Jonsson, A., Josephson, B. \& Vinnars, E. (1970). F. appl. Physiol. 29, 307.

Hecker, J. F. \& Nolan, J. V. (1971). Aust. F. biol. Sci. 24, 403.

Hogan, J. P. (1964). Aust. F. agric. Res. 15, 397.

Hoogenraad, N. J., Hird, F. J. R., Holmes, I. \& Millis, N. F. (1967). F. gen. Virol. r, 575.

Houpt, T. R. (1970). In Physiology of Digestion and Metabolism in the Ruminant p. I 9 [A. T. Phillipson, editor]. Newcastle upon Tyne: Oriel Press.

Houpt, T. R. \& Houpt, K. A. (1969). Am. F. Physiol. 214, r296.

Hungate, R. E. (1966). The Rumen and its Microbes. New York: Academic Press Inc.

Hungate, R. E. (1967). In Handbook of Physiology Vol. 5, Ch. 130, p. 2725 [C. F. Code and W. Heidel, editors]. Baltimore: Williams \& Wilkins, Co.

Juhász, B. (1965). Acta. vet. Acad. Sci. hung. 15, 25.

Lewis, D. (1955). Br. F. Nutr. 9, 2 I 5.

Loosli, J. K., Williams, H. H., Thomas, W. E., Ferris, F. H. \& Maynard, L. A. (r949). Science, N.Y. II0, I 44 .

McDonald, I. W. (1962). Proc. N.Z. Soc. Anim. Prod. 22, 79.

McDonald, I. W. (1968). Aust. vet. $\mathcal{~}$. 44, I45.

Martin, A. E. \& Ross, P. J. (1968). 9th Int. Congress of Soil Science Transactions, Adelaide, Australia, $3,52 \mathrm{I}$.

Mason, V. C. (1969). F. agric. Sci., Camb. 73, 99.

Nelder, J. A. \& Mead, R. (1965). Computer $\mathscr{7} .7,308$.

Phillipson, A. T., Dobson, M. J., Blackburn, T. H. \& Brown, M. (1962). Br. F. Nutr. x6, I 5 I.

Pilgrim, A. F., Gray, F. V. \& Belling, C. B. (1 969). Br. F. Nutr. 23, 647.

Pilgrim, A. F., Gray, F. V., Weller, R. A. \& Belling, C. B. (1970). Br. Э. Nutr. 24, 589.

Portugal, A.V. (1963). Some aspects of protein and amino acid metabolism in the rumen of sheep. PhD Thesis, University of Aberdeen.

Portugal, A. V. \& Sutherland, T. M. (т966). Nature, Lond. 209, 5 Io.

Rescigno, A. \& Segre, G. (1966). Drug and Tracer Kinetics. Waltham: Blaisdell.

Smith, R. II. (I g69). F. Dairy Res. 36, 313 .

Somers, M. (ig6r). Aust. F. exp. Biol. 39, i I 1 .

Thornton, R. F., Bird, P. R., Somers, M. \& Moir, R. J. (1970). Aust. F. agric. Res. 21, 345.

Virtanen, A. I. (1966). Science, N.Y. ז53, r603.

von Engelhardt, W. \& Nickel, W. (1965). Pflügers Arch. ges. Physiol. 286, 57.

Waldo, D. R. (1968). F. Dairy Sci. 5r, 265.

Warner, A. C. I. (1956). F. gen. Microbiol. 14, 749 .

Weston, R. H. \& Hogan, J. P. (1967). Aust. F. biol. Sci. 20, 967.

White, R. G., Steel, J. W., Leng, R. A. \& Luick, J. R. (1 969). Biochem. J. Ir4, 203.

Wright, D. E. \& Hungate, R. E. (1967). Appl. Microbiol. 15, 152. 